\title{
The Communication Aspect of Business Negotiations in the Intercultural Context
}

\author{
Milena Helmová \\ Faculty of Applied Languages, University of Economics, Slovak Republic
}

Copyright $\bigcirc 2017$ by authors, all rights reserved. Authors agree that this article remains permanently open access under the terms of the Creative Commons Attribution License 4.0 International License

\begin{abstract}
In the current era of social processes all over the world, the demands on the culture of communication increases, but on the other hand we are more aware of differences in thinking and acting of individuals coming from different cultural backgrounds. These facts are reflected in the international business negotiations, which require some specific abilities and knowledge influencing the successful result of mutual communication from negotiators. In fact, it is impossible not to communicate. There is communication everywhere and all the time. Within the context of this topic, we put a question: How can we communicate properly and successfully with a foreign business partner? In that connection, the cultural background of our business partner is important. There arise frequent misunderstandings during business negotiations because of the partner's different cultural background, which is reflected in their thinking and acting. The aim of this paper is to highlight the importance and direct connection of intercultural literacy as one of the conditions for successful communication in negotiation processes. The paper presents some theoretical starting points for the topic; it offers the views of the problem of interculturality by several theoreticians, and tries to reply the questions directly connected with intercultural business negotiations: what is the impact of my partners' culture on their behavior and thinking? Is intercultural communication only a product of communication in a foreign language, or is it something more than that? What does the intercultural competence of the negotiator mean, and how can it be acquired?
\end{abstract}

Keywords Business Negotiations, Communication, Intercultural Aspect, Communication Competence

\section{Introduction}

In the current phase of the information society development, we can observe a rising significance of communication in all spheres of life. Communication literacy as well as communication and socio-cultural competences, and communication skills are increasingly more required from professionals. Most authors describe communication from the viewpoint of their professional aspect. The theory of communication perceives it as social interaction [24]; managers understand it as a set of measures leading to achievement of the desired result and simultaneously, but not as a means of making oneself understood. [5] Psychology in its turn claims that communication is the most significant form of social contact, and it rests in sending and receiving signals or messages. [23]

In the field of business and business relations, communication abilities and skills have become a prerequisite for entrepreneurial success in an increasingly aggressive competitive environment. Communication represents the most important form of social interaction; consequently, it plays a crucial role in the contact of cultures. The socio-psychological research in communication means, communication channels, and in communication functions is a source of important knowledge for further exploration of cultural determinants of communication processes. [13] These needs and requirements are reflected in business negotiations, too.

Negotiations are a complex process. They represent a specific form of communication. Statistics reveal that every individual negotiates three to five times a day, without even realizing that they are conducting negotiations. [15] Participants of negotiations intend to push their goals through, fulfill their ideas, and gain various advantages. Negotiation processes are in general perceived in this sense. For a more thorough analysis, however, it is insufficient to approach negotiations in such a one-sided way. On condition that the negotiation partners desire to achieve optimum result, i.e. to reach the set goals, they must also take into consideration other factors, contributing to the overall optimization of the negotiation process. From the perspective of complexity, it is impossible to view negotiations merely as a targeted, matter-of-fact discussion. The whole process is enhanced by the negotiation participants' personalities, by the form of communication between them, and by the level of negotiations, i.e. whether 
they are held on national or international level.

International negotiations are viewed as intercultural because the preconditions for successful communication between partners include, apart from the complex of professional knowledge and skills, the knowledge of the partner's cultural background as well. The consequences of global changes call for the ability of mutual understanding. The fact stemming from intercultural interactions is that it is not only the language that distinguishes people of different nations, but also certain cultural patterns of behavior created in a long-term process of development. [4] The communication in both intracultural and intercultural business negotiations is conducted according to the general rules of communication model on the grounds of the information exchange between the communicators. Nevertheless, in the intercultural context of negotiations, the knowledge of cultural characteristics and customs of the other party is its inevitable component. The most significant result of Samovar's research [16] in this respect is the observation that each instance of communication is a reflection of its own cultural identity and contains specific, individual features. Because every human being is unique, communication will always be unique as well.

The questions of successful communicating, mutual understanding, and adequate acting have been an issue of the last few decades, particularly in respect of mutual contact between representatives of different cultures either in their professional life or in the private one. The author of the paper carried out two surveys related to the topic. One survey focused on bilateral Slovak - German business negotiations; the other one on the problems of introducing intercultural trainings in firms in Slovakia. In order to manifest the relevance of earlier formulated questions, the results are presented in the paper.

\subsection{Methodology}

The text is aimed at clarifying the mutual relation between culture and communication. It attempts to enhance the awareness of the direct relation and influence of the intercultural background of communicators on the success of communication. The aim of this article is to establish the measure to which the value systems of communication partners influence the outcome of negotiation process in both in the positive and in the negative sense. Moreover, the article intends to demonstrate that there exist means and methods of preventing and eliminating possible misunderstandings and problems in intercultural negotiations. Methodologically, the text is based on the research of specialist scientific literature, and it highlights and emphasizes research results and findings of renowned scientists and scholars from the fields of communication, intercultural competence, and cultural studies, as well as by means of the partial results of the two surveys conducted by the author.

\section{Intercultural Aspect of Business Negotiations}

The notion of culture does not cover only music, fine arts, language, literature or film. Members of different cultures as individuals express themselves by their specific everyday behavior, their style of work, relationship to the environment, as well as in many other areas, which influence and shape their cultural image. All of these aspects belong to the concept of culture. Hofstede defines culture as a mindset of an individual, distinguishing one culture from another. This unique know-how is reflected in their ways of thinking, feeling, and behavior. [9] The author claims that at first sight cultures of nations can be understood only to some extent. However, we can identify them through learning about the values and standards of their representatives, which are reflected in their actions. Hofstede assumes that in everyday contact with foreigners, the true characteristics of their culture will not manifest themselves. Thomas perceives culture as a universal phenomenon, which manifests itself in the orientation system of a nation, society, or group as a characteristic feature. The system is contains specific symbols, e.g. speech, gestures, facial expressions, way of dressing, rituals, greetings, and it is passed down from generation to generation. The system of orientation defines for all the members their affiliation and enables them to cope with their environment. Triandis [22] describes culture as part of the living environment created by people. The precondition of learning about and understanding of a foreign culture is a deep knowledge of one's own culture, of the patterns of thinking as well as the patterns of behavior of oneself and members of one's cultural environment. Behavior of individuals is determined by both the development of culture under the influence of historical events and individual personal features of its bearers. In order to be successful in international negotiations, it is important to realize the differences in comparison with one's own culture and make efforts to understand the partner's behavior in mutual interactions. If culture is understood as a certain orientation system, then it is appropriate to consider which cultural specificities can become sources of misunderstandings and problems.

The perception of time and space is a highly probable source of misunderstandings. Different cultures view time differently, e.g. when negotiating and signing business contracts. For example, Americans prefer fast conclusion of business contracts; other nations, on the contrary, tend to spend much more time on this process. Punctuality is typical for Germans; on the contrary, in African cultures it is not important when the negotiation partners meet - what is crucial is that they meet at all. Hall [6] delimitated the aspect of handling time as one of fundamental factors of distinguishing cultures. In respect of the perception of time, there are consequences derived from it for the negotiators. These relate to mutual communication and involve the 
length of small talk, speed of concluding contracts, timing of individual phases of negotiations, and breaks. Space is perceived by different cultures differently, too. Negotiations themselves take place in some space, which thus becomes part of the communication. With regard to intercultural negotiations, partners should pay due attention to such aspects as distance zones during negotiations, movement of the partner in the space, set-up of the negotiating place, and the roles of private and public spaces. Cultures differ from each other by the motion in space as well. Schefflen [17] denominates the social use of space as kinesics. We have to take into consideration that there are cultures perceiving physical closeness positively and others that view it negatively. Thus by keeping an appropriate distance from the communication partner, negotiators show their understanding and respect for the partner's tradition. Another aspect of cultural difference is the style of communication. In his studies, Samovar [16] points out three aspects of behavior in space in relation to intercultural differences. The first differentiating criterion is the high- or low-context communication [6], i.e. whether or not the communication focuses on the partner; whether the participant of communication can 'read between the lines' and also sends non-verbal signals apart from verbal messages; or whether the participant of communication favors direct communication style and endeavors to save their own face. The second aspect, according to Samovar, is formal or informal communication connected to the use of titles, dress code, and strict observation of rules. The third differentiation aspect relates to the communication habits of cultures. On the one hand, it is about reinforcing the individual, open confrontation, even aggression and loudness of expression, as can be seen with Americans; on the other hand, the focus is on harmonious relations when partners try to avoid confrontations (Asian cultures). Misunderstandings between business partners occur not only because of the lack of knowledge of the culture-specific behavior, but even due to the inability to choose the most appropriate scenario out of the miscellany of the possible ones.

The empirical study, as Helmová informs [7], for everyday experience there indicates also new facts related to mutual perception of cultural behaviors, which corroborates the proposition that cultures are not static: instead, they are developing. The survey was participated by tens of Slovak and German managers - negotiators. Both samples agreed that their knowledge about the partner's culture could be rated at six-digit evaluation scale: inadequate, more inadequate than adequate, average, rather extensive, extensive, very extensive, and average only. This fact ensues from respondents' personal (subjective) evaluation about their present foreign experience in their negotiation partner's country. As much as 71 percent of respondents in the German sample have never been in Slovakia and 37.5 percent of Slovaks have not visited Germany. Standardized cultural behaviors in the two countries are essentially different, according to Hofstede. The German culture is presented as individualistic, the Slovak one more or less as collectivistic. When considering this difference, then the evaluation - average knowledge of the partner's culture - points to superficial, rather general knowledge, which indicates the possibility of problems or misunderstandings, in particular in the relationship of Germans to Slovaks. After the 1989 revolution, Slovaks have manifested some features of individualism. This change has occurred mainly in large industrial centers, while in rural areas the process has been slower. Another fact connected with the partner's culture background ensues from the analysis of pre-negotiation stage for business negotiations, which should contain collecting various information about the other party, including also their country and culture. The survey shows that representatives of both the German and Slovak cultures fail to pay attention to this need for acquiring information about the partner's country in the pre-negotiation stage. They focus on acquiring information about the market and industry, about the partner's firm, about the firm's strategic plan, and the partner's business interests. Our survey indicates considerable differences in behavior between German and Slovak managers in some situations, which resulted in misunderstandings. Contemporary Slovak negotiators think and act with more assertiveness and independence, which is, however, perceived by German partners as cheeky behavior. We can state at this point, that only if partners manifest an adequate capability of respecting each other's culture and understanding each other's behavior, problem situations may be eliminated.

Intercultural communication is characterized by Broszinsky Schwabe as an exchange of messages between people coming from different cultures. Patterns of behavior are acquired already in early childhood, from which follows that in interactions with representatives of other cultures, communication is shaped not only by a different language, but mainly by cultural specificities. [4] It is evident, as the author claims, that it is the awareness of the mutual cultural differences between the partners in thinking, behavior, and acting that plays a decisive role in successful business negotiations. Maletzke [12] distinguishes structural features of cultures and labels them as categories, by which cultures differ and constitute their own specific profile. These features include perception, non-verbal communication, time and space management, language, and behavior. Hofstede [9] is an author of the theory of cultural differences based on cultural dimensions representing typical properties of various national cultures. They include power distance, individualism and collectivism, masculinity and femininity, uncertainty avoidance, and short- versus long-term time orientation. Optimum intercultural communication is part of a permanent process of cognition and learning, the consequence of which is the perception of another culture in its essence and variety, and it consists in the adjustment to and understanding of these differences. 
Apart from verbal communication, a significant role in intercultural communication is played by non-verbal communication as it is also shaped by cultural patterns. It gains its unique significance particularly in situations when partners resort to non-verbal means of expression due to limited linguistic communication possibilities and skills. The notion of intercultural communication was introduced by Hall [6], and it covers two levels of understanding. In the narrow sense, it denotes a face-to-face communication between two individuals with different cultural backgrounds, using language and non-verbal signals. In the broader sense of the notion, intercultural communication is viewed as both interpersonal communication between culturally different partners and its mediated level in all its forms as characterized by Lüsebrink. [11] The success of intercultural communication rests not only in whether or how an individual masters the language of their business partner, but especially in the awareness of the fact that all individuals are objects of the process of their culture's socialization; for this reason they behave and act the way they do.

The paper analyzes communication skills of Slovak and German negotiators, as well as the frequency of using English as the first language of negotiation in mutual negotiations. Our survey results indicate that 50 percent of Slovak negotiators use only German; 3 percent of them only English, and the remaining percentage of Slovak respondents combine the two languages. The fact that Slovaks prefer German to English can be understood as the consequence of a larger geographical distance between both cultures, as well as the effort to send a signal to the negotiation partner of our interest in them and their culture. 58 percent of German negotiators opt for English in combination with German. German (only) is used only by 7 percent of German respondents; 14 percent of negotiators use mainly English and some Slovak; 7 percent speak mainly German and some English in negotiations. It is interesting to observe that 14 percent of Germans use exclusively Slovak in negotiations with Slovaks. Both cultures differ also in terms of the communication style. Direct, factual, and formal argumentative style of communication of German negotiators is often perceived by Slovaks as confrontational, even undiplomatic. Diametrically opposed to that is an indirect way of communication, characteristic for Slovaks, which is determined by the feeling of harmony, motivated by an effort to avoid problems. We can state that in negotiations, the function of language factor as means of communication and style of communication rests not only in the exchange of information, but also in cultural dimension, as Helmová claims [7].

Intercultural interactions do not always lead to understanding of communication partners. Frequently, various misunderstandings and problems occur. The reason, according to Herbrand [8] is that intercultural contacts are much more complex than intracultural ones. There arises a gap between the domestic culture and the foreign culture, which is full of vague messages, hesitations, and new moments, because partners are bearers of particular attitudes to the world, views of life, ways of thinking and acting. Due to the fear of otherness, these factors lead to clashes in intercultural communication. [21] In order to prevent from intercultural conflicts and secure smooth process of business negotiations, intercultural competence is inevitable. The ability to perceive, understand, and productively assess intercultural situations is an outcome of intercultural competence. The notion of intercultural competence implies a complex theoretical construct. Thomas [20] describes intercultural competence as an ability to understand cultural facts and factors that influence one's own perception, thinking, feeling, and acting and that of other individuals, including an ability to respect them; as the skill of using them productively in interaction in the spirit of tolerance and peaceful coexistence; and an ability to employ these orientation models in relation to the interpretation of the world in its diversity. Bolten [2] defines intercultural competence as a set of several abilities (competences) which participate in constituting intercultural competence. The author discusses the ability of acculturation - accepting the values and patterns of thinking of another culture into one's own culture; he perceives intercultural situations as opportunities rather than threats. Yousefi [25] claims that intercultural competence is a process of acquiring information and behavioral patterns, which make it possible to cope with the challenges of intercultural situations. Acquiring intercultural competence, according to him, becomes inevitable when differing forms of thinking, behavior, and living habits get into conflict. Over the past few years, intercultural competence has become a key competence. The importance of acquiring and developing intercultural competence is proven by the fact that it is needed in almost all spheres of life. We can consider it an interdisciplinary competence. It is relevant for people, who live and work abroad, for managers in multinational corporations in their own country and abroad, at work in multicultural teams. It is equally important to internationally active negotiators, for whom mastering a foreign language is no longer sufficient. What is vital is the knowledge of the partner's culture in its complexity. Intercultural competence is not inherited; it has to be acquired and constantly cultivated.

A sensitive background to the partner's culture-specific behavior is one of the most significant factors of preventing from and dealing with intercultural clashes. The paper points to several causes of their origin mentioned by respondents. The core of misunderstandings is limits between working life and personal life in the case of Germans, or wiping away these limits by Slovaks, which is manifested (as the survey analysis indicates), by Slovaks' inclination to speak about one's personal problems at work. In Germans, this kind of behavior breeds resentment, and they perceive it as nuisance. As Germans themselves indicate they have to be very patient when collaborating with Slovaks. Over one-fifth of German 
respondents mention their bad experience with Slovaks' time management. Their opinion of the reason is unanimous: they claim that the problems stem from bad organization and unsatisfactory time planning. While Germans plan their working and personal programs in detail, and in case the plan is disturbed, they are unable to flexibly react, Slovak respondents have a flexible attitude to time perception: they view deadlines as approximate, serving for the purpose of orientation. German negotiators cannot identify with Slovaks' late arrivals to negotiations, which may, according to Helmová [7], result in disrupting mutual business relationships.

With regard to the needs of the society as well as the world development, the question arises how it is possible to acquire intercultural competence. One of the ways leading to the acquisition and development of intercultural competence is intercultural education. The process of intercultural learning is viewed as a dynamic process, based on comparing one's own culture with the foreign culture. The content focuses on defining the processes, leading to acquisition of the knowledge of the foreign culture. In the process of intercultural education, the key point is to overcome the ethnocentric approach, preferring one's own culture to the partner's culture. Its goal is to eliminate the prejudice and stereotypes regarding the partner's culture, to accept cultural differences, and respect cultural diversity. Globally, the best-known training program is Culture Assimilator. The method originated in the USA and later took roots in Germany, especially owing to Alexander Thomas. [19] The method incorporates numerous case studies, in which typical problem situations are modeled and the trainee becomes familiar with numerous incomprehensible reactions of other cultures' representatives. These problem situations are denoted as Critical Incidents. With each incident, several options for its handling are introduced, of which only one is correct and the trainee must identify it. The benefit dwells in the fact that this method sensitizes cultural differences. According to Straub [18], the aims of intercultural learning and acquiring intercultural competence include: studying intercultural contents; developing the ability to deal with problematic situations in communication (Critical Incidents); acquiring both foreign language and social competence; eliminating fear and increasing the ability to tolerate ambiguity in interactions; expanding the awareness of cultural dimensions; and developing information processing or increasing of flexibility and adaptability. These aims complement each other and cannot be separated. In order to achieve them, several methods are employed in the process of intercultural learning. Straub speaks of formal and informal learning. According to him, the informal learning is occurs in unexpected situations, which arise at random in one's life. The lesson derived from such situations, however, does not necessarily mean the development of intercultural competence as it was recorded subconsciously and was not reflected in one's behavior. The formal intercultural learning is understood as a set of consciously planned and organized processes of learning.

Regarding the acquisition of intercultural competence, Bolten [1] considers two types of learning processes: off-the-job-process and on-the-job-process. The first one is related to training, which is not immediately connected to the working environment and takes place in artificial conditions, e.g. in the form of external continuing training. The second type is characteristic of its connection to the working environment. It takes place in multicultural teams where the learners gain hands-on experience. In general, intercultural training contains all measures designed to mediate and make possible the constructive adaptation to the foreign culture, appropriate assessment and decision-making as well as efficient behavior in intercultural situations. Several types of intercultural trainings are described in professional literature; we will deal with them later. First, it may be useful to explain the goal of intercultural trainings, as proposed by Bolten. The main goal is practicing intercultural competence, as mentioned earlier. Apart from the main goal, the trainings focus also on partial goals, depending on the type of trainees (business sphere, emigrants, etc.). Brislin and Yoshida [3] identified four basic goals of intercultural trainings. First, they are meant to help the trainees overcome the obstacles, with which they may be confronted. Second, they are designed to facilitate creating positive relations with people in foreign countries. Third, they are aimed at the fulfillment of professional tasks and, finally, they are supposed to eliminate stress, and in this way the trainees are taught to act more courageously. Subsequent to the afore-mentioned types of intercultural trainings, Bolten [1] highlights four forms: culture-specific informative trainings, multicultural informative trainings, culture-specific interactive trainings, and multicultural interactive trainings. The trainings in the form of lectures focus on the mediation of theoretical knowledge of culture, and those in the form of workshops focus on practicing intercultural competence. The problem of intercultural training is an extensive topic, and its thorough elaboration requires a much broader perspective. Our intention was to introduce intercultural trainings only as one of the forms of acquiring intercultural competence.

However, in this context, we intend to publish results of survey into the rate of dissemination of intercultural trainings in businesses registered in the Slovak - German Chamber of Commerce and Industry in Slovakia. In the year 2015, the share of foreign capital was over 40 percent on the Slovak economy, of that the largest part of investment was businesses from Germany. It is obvious that businesses need to deal with the issues of interculturality, and therefore it is reasonable to assume, that a leading place in business interests of management should be occupied by the effort for developing employees' intercultural competence. As many as 105 foreign firms with residence in Slovakia participated in the survey/research. Respondents were asked to reply to the question: "Are there intercultural trainings introduced in 
your firm?" Simply, yes or no. Based on respondents' replies, authors Odvarkova and Helmova [14] interpreted the finding that almost 85 percent of firms replied in the negative, while only 15 percent answered in the affirmative. According to them, these results indicate that firms are familiar with intercultural trainings and organize them. Respondents informed that in their businesses intercultural trainings were part of their induction employee programs. We can conclude that given the importance of intercultural competence for internationally active negotiators, the result of the survey is far from flattering.

According to the research, up to $70 \%$ of corporations fail due to intercultural barriers. [10] For numerous companies, intercultural trainings represent an opportunity that brings a long-term profit. One of the intentions of this paper is to introduce intercultural trainings as an appropriate form of intercultural competence acquisition.

\section{Conclusions and Policy Implications}

In business negotiations with foreign partners, each individual represents themselves and their company as well as their country, which requires a thorough preparation of not only appropriate strategies, tactics, and techniques, but to the same extent, the knowledge of cultural specificities and customs of the partner's country. Cultural differences, social, economic, and religious situation of the country must be handled with sensitivity. A judicious and competent behavior and action are signs of negotiators' professional approach, which have already become indivisible parts of negotiations with a foreign partner. Cultural difference does not mean that any culture is better or worse than another one. It merely indicates that it is different from the first one. Sensitivity to intercultural issues means understanding that the values and cultural standards of other people should be accepted as having the same validity as ours. It is obvious that world cultures endeavor to preserve their national identities, consequently, the cultural otherness manifested in communication even stronger. Therefore, it is important to gain orientation in the standards and values of various cultures' representatives, which are reflected in their behavior and actions. Intercultural competence has in fact turned into a necessity. This skill is expected particularly from internationally active negotiators.

As mentioned earlier, progressing globalization gives opportunities for making new business contacts. It is evident that in spite of professional erudition and language competence of business partners in some problems may arise. The reason is the underestimation of the cultural aspect. It is thus reasonable to claim that the acquisition and development of intercultural competence should be given adequate consideration in the course of pre-negotiation stage. It is often the intercultural maturity of negotiators that decides about how successful the negotiations are and whether the aim is reached.
Our intention of discussing the selected topic was to point out the mutual interconnection of the business negotiations process in intercultural context and intercultural competence. The paper tried to find answers to the afore-mentioned questions. Based on theoretical approaches of various authors, we explored the topic from several viewpoints and arrived at the conclusion that interconnection and interdependence of both constructs, i.e. international business negotiations and intercultural competence, was manifested in the effort to achieve the goal of negotiations.

In conclusion, it is inevitable to emphasize some reasons for introducing intercultural trainings in business companies. First of all, these trainings provide a thorough preparation and increase the chance of success in negotiations. Furthermore, they enable to raise awareness of one's own culture, one's own ability to communicate successfully in negotiations, without which the sensitization of a foreign culture is rather improbable. Finally, owing to the ability of avoiding and solving possible misunderstandings in intercultural communication, there is a chance of increasing the negotiators' motivation to collaborate. We are convinced that in this respect it is desirable that negotiators seek opportunities to know their business partners better, even outside of negotiation schedules, and thus identify priorities in the business sphere and those related to the human factor.

\section{REFERENCES}

[1] J. Bolten. Interkultureller Trainingsbedarf aus der Perspektive der Problemerfahrung entsandter Führungskräfte, In Interkulturelles Lernen / Interkulturelles Training, Hampp, pp. 55-77, München, 2006.

[2] J. Bolten. Interkulturelle Kompetenz, Landeszentrale für politische Bildung, Tübingen, 2007.

[3] R. W. Brislin, T. Yoshida. Intercultural communication training, An introduction, Sage, Thousand Oaks, 1994.

[4] E. Broszinsky-Schwabe. Interkulturelle Kommunikation, Missverständnisse, Verständigung, Springer, Wiesbaden, 2011.

[5] P. F. Drucker. Was ist Management, Das Beste aus 50 Jahren, Klett Lernen und Wissen GmbH, Stuttgart, 2007.

[6] E. T. Hall. The Silent Language, Garden City, New York, 1959.

[7] M. Helmová. Stratégie a taktiky obchodných rokovaní v procese globalizácie, Bratislava, Online available from ftp://ipeu:193@193.87.31.84/0136597/2011FMVHELMOV A_M.pdf

[8] F. Herbrand. Fit für fremde Kulturen, Interkulturelles Training für Führungskräfte, Verlag Paul Haupt, Bern/Stuttgart/Wien, 2002. 
[9] G. Hofstede. Culture's consequences, International differences in work related values, Sage, Beverly Hills, 1980.

[10] Akademie für interkulturelles Management, Interkulturelles Training Deutschland, Global Cultures, Online available from http://global-cultures.com

[11] H. J. Lüsebrink. Interkulturelle Kompetenzen, Erfolgreich kommunizieren zwischen Kulturen, Klett Lernen und Wissen, Stuttgart, 2007.

[12] G. Maletzke. Interkulturelle Kommunikation, Zur Interaktion zwischen Menschen verschiedener Kulturen, Westdeutscher Verlag, Opladen, 1996.

[13] I. Nový, S. Schroll Machl. Spolupráce přes hranice kultur, Management Press, Praha, 2005.

[14] M. Odvarková, M. Helmová. Interkulturelle Kompetenz in den deutsch-slowakischen Geschäftsverhandlungen, Bratislava, 2015, Online http://www.crzp.sk/crzpopacxe/open URL? crzpSigla $=$ eubratislava\&crzpID $=3$ a8f0665-eb80-4331b765a35ec844e 3 c2

[15] M. Opresnik. Die Geheimnisse erfolgreicher Verhandlungsfü hrung, Besser verhandeln in jeder Beziehung, Verlag Berlin, Heidelberg, 2014.

[16] L. Samovar, et al. Communication between Cultures, Wadswoth Thomson Learning, Australia, Canada, Mexico, Singapore, Spain, United Kingdom, United States, 2001.

[17] A. Scheflen. Körpersprache und soziale Ordnung, Kommunikation als Verhaltenskontrolle, Klett-Cotta-Verlag, Stuttgart, 1976.
[18] J. Straub, S. Nothnagel, A. Weidemann. Interkulturelle Kompetenz lehren, Begriffliche und theoretische Voraussetzungen. In Weidemann/Straub/Nothnagel (Hrsg.), Wie lehrt man interkulturelle Kompetenz, Theorien, Methoden und Praxis in der Hochschulausbildung, Ein Handbuch, Transcript Verlag, Bielefeld, 2010.

[19] A. Thomas, S. Kammhuber, S. Schroll Machl. Handbuch Interkulturelle Kommunikation und Kooperation, Bd. 2, Länder, Kulturen und interkulturelle Berufstätigkeit. Vandenhoeck \& Ruprecht, Göttingen, 2003.

[20] A. Thomas. Analyse der Handlungswirksamkeit von Kulturstandards, In A. Thomas (Hg.), Psychologie interkulturellen Handelns, Hogrefe, Göttingen, 2003.

[21] A. Thomas. Das Eigene, das Fremde, das Interkulturelle. In Thomas Alexander/Kinast Eva-Ulrike/Schroll-Machl Sylvia, Handbuch Interkulturelle Kommunikation und Kooperation, Bd.1, Grundlagen und Praxisfelder, Vandenhoeck \& Ruprecht Verlag, Göttingen, 2003.

[22] H. Triandis. Intercultural Education and Training, In Funke, P. (Hg.), Understanding the U.S., Across Culture Prospective. Tübingen, 1989.

[23] J. Vymětal. Pruvodce úspěšnou komunikací, Efektivní komunikace v praxi, Grada Publishing, Praha, 2008.

[24] P. Watzlawick, J. H. Beavin, D. D. Jackson. Menschliche Kommunikation, Formen, Störungen, Paradoxien. Huber Verlag, Bern, 2011.

[25] H. R. Yousefi. Grundbergiffe der interkulturellen Kommunikation, UTB, Stuttgart, 2014. 